\title{
Barriers to Radiation-Induced In Situ Tumor Vaccination
}

\author{
Erik Wennerberg', Claire Lhuillier ${ }^{1}$, Claire Vanpouille-Box ${ }^{1}$, Karsten A. Pilones', \\ Elena García-Martínez ${ }^{1,2}$, Nils-Petter Rudqvist', Silvia C. Formenti' and Sandra Demaria ${ }^{1 *}$ \\ 'Department of Radiation Oncology, Weill Cornell Medicine, New York, NY, USA, ${ }^{2}$ Department of Hematology and Medical \\ Oncology, University Hospital Morales Meseguer, Murcia, Spain
}

OPEN ACCESS

Edited by:

Udo S. Gaipl,

University Hosptial Erlangen,

Germany

Reviewed by:

Franz Rödel,

University Hospital Frankfurt, Germany

Alan Graham Pockley,

Nottingham Trent University, UK

*Correspondence:

Sandra Demaria

szd3005@med.cornell.edu

Specialty section:

This article was submitted to Cancer Immunity and Immunotherapy,

a section of the journal

Frontiers in Immunology

Received: 10 January 2017 Accepted: 17 February 2017

Published: 13 March 2017

Citation:

Wennerberg E, Lhuillier C, Vanpouille-Box C, Pilones KA, García-Martínez E, Rudqvist N-P, Formenti SC and Demaria S (2017) Barriers to Radiation-Induced In Situ Tumor Vaccination.

Front. Immunol. 8:229. doi: 10.3389/fimmu.2017.00229
The immunostimulatory properties of radiation therapy $(R T)$ have recently generated widespread interest due to preclinical and clinical evidence that tumor-localized RT can sometimes induce antitumor immune responses mediating regression of nonirradiated metastases (abscopal effect). The ability of RT to activate antitumor T cells explains the synergy of RT with immune checkpoint inhibitors, which has been well documented in mouse tumor models and is supported by observations of more frequent abscopal responses in patients refractory to immunotherapy who receive RT during immunotherapy. However, abscopal responses following RT remain relatively rare in the clinic, and antitumor immune responses are not effectively induced by RT against poorly immunogenic mouse tumors. This suggests that in order to improve the pro-immunogenic effects of RT, it is necessary to identify and overcome the barriers that pre-exist and/or are induced by RT in the tumor microenvironment. On the one hand, RT induces an immunogenic death of cancer cells associated with release of powerful danger signals that are essential to recruit and activate dendritic cells (DCs) and initiate antitumor immune responses. On the other hand, RT can promote the generation of immunosuppressive mediators that hinder DCs activation and impair the function of effector T cells. In this review, we discuss current evidence that several inhibitory pathways are induced and modulated in irradiated tumors. In particular, we will focus on factors that regulate and limit radiation-induced immunogenicity and emphasize current research on actionable targets that could increase the effectiveness of radiation-induced in situ tumor vaccination.

\section{Keywords: abscopal effect, adenosine, hypoxia, immunotherapy, macrophages, radiation therapy, transforming} growth factor- $\beta$, tumor microenvironment

\section{INTRODUCTION}

Immune checkpoint blockade with antibodies targeting cytotoxic $\mathrm{T}$ lymphocyte-associated protein 4 (CTLA-4) and programmed cell death protein-1 (PD-1) has shown durable responses in a significant portion of patients with metastatic cancer. However, patients that lack pre-existing antitumor immunity are generally unresponsive to these therapies (1). In these patients, treatment with immune checkpoint inhibitors needs to be combined with a strategy to induce de novo tumorspecific T cells. Recent findings have shed light on the potential of radiation therapy (RT) to induce such responses (2). 
Exposure of tumor cells to ionizing radiation (or certain cytotoxic chemotherapy agents) can result in immunogenic cell death (ICD) whereby upregulation or release of dangerassociated molecular patterns (DAMPs) including calreticulin, high-mobility group protein $\mathrm{B} 1$, and adenosine triphosphate (ATP) alerts the immune system of a potential threat $(3,4)$.
The release of DAMPs associated with RT-induced cancer cell death occurs in a dose-dependent fashion and has been shown to both recruit and activate dendritic cells (DCs) to uptake tumor antigens and cross-present them to naïve $\mathrm{T}$ cells thus initiating antitumor immune responses (Figure 1) (5-9). RT can also facilitate the recruitment of effector T-cells to the tumor

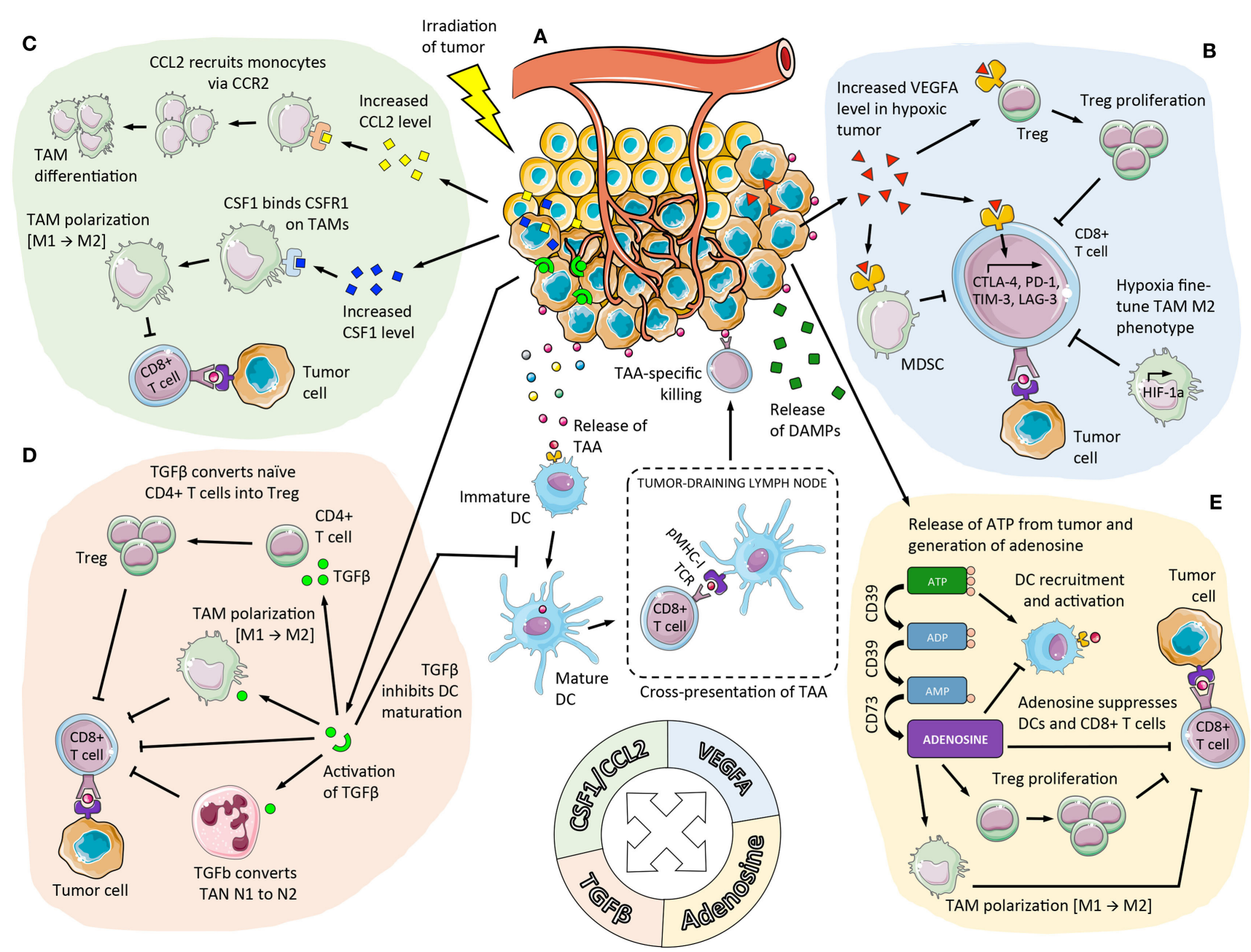

FIGURE 1 | Immunosuppressive pathways enhanced by RT in the TME that limit RT-induced in situ vaccination. (A) DCs are recruited to the tumor and activated following RT-mediated induction of ICD and subsequent release of DAMPs in the TME [including ATP, depicted in (E)]. After uptake of TAAs that are released from dying tumor cells DCs become activated and migrate to tumor-draining lymph nodes where they cross-present the antigens to naiive T cells. The activated TAA-specific CD8 ${ }^{+} \mathrm{T}$ cells proliferate, acquire effector function, and infiltrate the irradiated tumor and abscopal sites where they eliminate tumor cells. However, RT promotes not only immune stimulation but also contributes to a suppressive TME that counteracts the newly initiated immune response. (B) Hypoxic regions within tumors have reduced sensitivity to RT and a suppressive TME that can be exacerbated following RT. RT upregulates transcription of HIF-1 $\alpha$ resulting in expression of a series of genes that promote immunosuppression, by inducing Treg proliferation, M2 polarization of TAMs, and MDSC activation. (C) C-C chemokine receptor type 2 (CCR2)-expressing monocytes are recruited to the tumor due to increased CCL2 levels following RT. In the tumor, monocytes then differentiate to TAMs. RT can also directly modulate TAMs through induction of CSF1 causing mobilization, proliferation, and polarization of TAMs to an M2 phenotype. (D) RT activates latent TGF $\beta$ within the tumor that causes conversion of CD4 ${ }^{+} \mathrm{T}$ cells to Tregs, and polarization of TAMs and TANs to an M2 and N2 phenotype, respectively. (E) Tumor cells undergoing radiation-induced ICD release ATP, which is rapidly catabolized into adenosine in the TME by ectoenzymes CD39 and CD73 expressed on tumor cells, stromal cells, and immune cells. Local accumulation of extracellular adenosine suppresses DCs and effector T cells while promoting proliferation of Tregs and a more suppressive phenotype in TAMs. DC, dendritic cell; ICD, immunogenic cell death; RT, radiation therapy; DAMPs, danger-associated molecular patterns; TAA, tumor-associated antigens; TME, tumor microenvironment; PMHC-1, peptide-loaded major histocompatibility class I complex; TCR, T cell receptor; HIF-1 $\alpha$, hypoxia-inducible factor- $1 \alpha$; VEGFA, vascular endothelial growth factor A; CTLA-4, cytotoxic T lymphocyte-associated protein 4; PD-1, programmed cell death protein-1; TIM-3, T-cell immunoglobulin and mucin-domain containing-3; LAG-3, lymphocyte-activation gene 3; Treg, regulatory T cell; TGF $\beta$, transforming growth factor $\beta$; TAM, tumor-associated macrophage; MDSC, myeloid-derived suppressor cell; CSF1, colony-stimulating factor 1; TAN, tumor-associated neutrophil; ATP, adenosine triphosphate. 
by inducing the secretion of CXC motif chemokine ligand (CXCL)9, CXCL10, and CXCL16 by tumor cells (10-12). In addition, RT-induced upregulation of major histocompatibility complex class I molecules, FAS/CD95, and stress-induced natural killer group 2D-ligands on tumor cells enhance recognition and killing of cancer cells by cytotoxic T cells (CTLs) (10, 13-15). Overall, these RT-induced signals have been shown to mediate, at least in part, the powerful synergy between RT and a variety of immune therapeutic agents, including immune checkpoint inhibitors and DC growth factors, in experimental settings where these treatments by themselves were ineffective. The most important result of this synergy is immune-mediated tumor regression in non-irradiated metastases, known as abscopal effect, which has been seen in preclinical models as well as patients and supports the interpretation that the irradiated tumor acts as an in situ vaccine generating a systemic antitumor response (16-21). However, abscopal effects remain rare, highlighting the need to better understand and address the obstacles to effective in situ vaccination by RT.

Once tumors are established, they have evolved multiple ways to escape immune-mediated control and elimination, often by creating an increasingly immunosuppressive microenvironment (22). Myeloid cells in the tumor microenvironment (TME) are polarized toward an immunosuppressive phenotype, and DCs acquire a tolerogenic function or are excluded altogether from the tumor (23). If effector $\mathrm{T}$ cells are present, they are unable to function due to inhibitory molecules expressed on tumor and stromal cells and/or a suppressive cytokine milieu (22). There are multitudes of signaling pathways that govern the suppressive nature of the TME, and the modulation of these pathways by RT is an active area of study.

Tumors, which often behave like non-healing wounds, are rich in tumor-associated macrophages (TAMs), whose suppressive properties are largely regulated by colony-stimulating factor 1 (CSF1), a growth factor that is upregulated in irradiated tumors (24). TAMs secrete transforming growth factor- $\beta$ (TGF $\beta$ ) and other cytokines that suppress effector T cells and stimulate regulatory $\mathrm{T}$ cells (Tregs). The TME contains large amounts of inactive TGF $\beta$, which can be converted to its active form by RT, as discussed below. In addition to its stimulatory effect on tumor angiogenesis, fibrosis, and cell growth, TGF $\beta$ has direct inhibitory effects on the antitumor immune response. Under conditions of hypoxic stress, which occurs commonly in growing tumors and can be further exacerbated following RT, tumor cells utilize hypoxia-inducible factors (HIFs) to induce expression of genes that help them cope metabolically with the low oxygen levels and vascularize the tumor tissue, including vascular endothelial growth factor A (VEGF-A). Moreover, the hypoxic TME contains high levels of adenosine, a pleiotropic immunosuppressive mediator that can be actively secreted from intracellular stores or generated by extracellular catabolism of ATP released following cellular stress including RT-induced $\operatorname{ICD}(5,25)$. In this review, we will discuss how RT regulates these fundamental immunosuppressive pathways, how they interact and affect each other and importantly, how they modulate the ability of RT to induce antitumor immunity.

\section{REGULATION OF TAMS IN THE IRRADIATED TUMOR}

TAMs comprise a major component of the inflammatory infiltrate in many solid tumors and for the most part promote a tolerogenic and immunosuppressive milieu. Their presence in ovarian, prostate, cervical, and breast malignancies is correlated with poor prognosis (26). TAMs can acquire functional properties that span the spectrum from M1 to M2-type tissue macrophages. Classically activated (M1) macrophages are highly phagocytic toward tumor cells, present antigens effectively and secrete pro-inflammatory cytokines essential for the recruitment and activation of $\mathrm{T}$ and natural killer (NK) cells (27). In contrast, under the influence of a Th2-type cytokine environment, macrophages become alternatively activated (M2) and perform tissue remodeling and immunosuppressive functions promoting tumor progression. In most tumor studies, TAMs have been shown to promote tumor invasion and metastasis $(28,29)$. This protumorigenic phenotype is highly influenced by the progressively growing tumor and by soluble factors secreted by both cancer cells and other infiltrating immune cells (30).

TAMs produce high levels of immunosuppressive IL-10 and stimulate angiogenesis that further supports tumor growth (31). However, in some malignancies such as lung and gastric cancer, the presence of TAMs correlated with a more favorable patient outcome, suggesting a high functional plasticity of TAMs, which may acquire M1-like properties in some tumors. Importantly, radiation can profoundly modulate TAM populations in several ways (a) it depletes TAM as well as immature myeloid cells, (b) it increases their recruitment, (c) it causes their re-distribution between areas of necrosis and hypoxia elicited by RT, (d) it changes their polarization toward either M1 or M2 phenotype, and (e) it improves the ability of macrophages to present tumor antigens $(32,33)$.

Although the molecular mechanisms that underlie the ability of radiation to provoke these effects remain incompletely defined, the activation of the signaling pathway mediated by the growth factor CSF1 plays a critical role. Binding of CSF1 to its cognate receptor tyrosine kinase colony-stimulating factor 1 receptor (CSF1R) rapidly initiates the proliferation, differentiation, and migration of tissue-resident macrophages (Figure 1) $(34,35)$. The CSF1/CSF1R pathway is critical in recruiting TAMs and promoting tumor growth. In patients with breast, prostate, and ovarian cancer, high CSF1 levels have been shown to correlate with poor prognosis (36-38). Furthermore, the prognostic value of a CSF1-responsive gene signature was validated in a subset of breast cancer patients, where it was shown to predict risk of recurrence and invasiveness $(39,40)$. The expression of CSF1 in a broad array of human and murine tumor cell lines was increased after irradiation in vitro as well as in vivo in implanted tumors (24). An increase in the levels of serum CSF1 was observed in prostate cancer patients receiving radiotherapy, suggesting that the radiation-induced CSF1 upregulation is clinically relevant. The molecular mechanism of RT-induced CSF1 upregulation was recently described in a mouse prostate carcinoma. The nonreceptor tyrosine kinase ABL1, which mediates apoptosis and cell cycle arrest and is activated following radiation, was shown 
to translocate to the nucleus and bind to the CSF1 promoter region. Importantly, blocking the CSF1/CSF1R signaling pathway using either a selective inhibitor (GW2580) or a highly potent small molecule inhibitor of CSF1R kinase (PLX3397) resulted in significant reduction in TAM infiltration and improved tumor control by RT in a mouse model (24), suggesting that the CSF1/ CSFR1 axis is an important therapeutic target.

Another chemokine implicated in the RT-induced myeloid cell recruitment to the tumor is $\mathrm{C}-\mathrm{C}$ motif ligand 2 (CCL2). In a mouse tumor model of pancreatic adenocarcinoma (PDAC), local delivery of a single 20 Gy dose markedly augmented the release of CCL2 by tumor cells, which was consequently accompanied by the infiltration of inflammatory macrophages expressing C-C chemokine receptor type 2 (CCR2, the cognate receptor for CCL2) (Figure 1) (41). The mobilization of inflammatory monocytes via CCL2/CCR2 axis has been described as a negative prognosticator in breast, pancreatic, and hepatocellular cancer, and its activation may further play a key role in mediating resistance of PDAC to ablative radiotherapy $(28,42,43)$. These findings suggest that CCL2/CCR2 antagonists currently under clinical evaluation may have a new role in the context of radiotherapy, where they could be used to improve patient responses (Table 1) (44-46).

\section{HYPOXIA IN RT-TREATED TUMORS AND IMMUNE REGULATION BY HIF-1 $\alpha$ AND VEGF-A}

Perturbation in oxygen homeostasis is a common feature of solid tumors, in which hypoxic regions are more resistant to RT. Indeed, ionizing radiation creates free radicals that are highly reactive due to their unpaired electrons and can therefore react with molecular oxygen leading to the production of reactive oxygen species (ROS). High concentrations of ROS, such as superoxide anion radical or hydrogen peroxide, can initiate harmful chemical reactions within the cells, including DNA damage. Thus, welloxygenated cancer cells are more sensitive to cytocidal effects of RT than hypoxic cells.

Hypoxia-inducible factor- $1 \alpha$ (HIF- $1 \alpha)$ is a key transcription factor induced by hypoxia that has been reported to correlate with a poor prognosis, local tumor recurrence, and distant tumor metastases after RT $(47,48)$. Upregulation of HIF- $1 \alpha$ in response to RT enhances endothelial cell radioresistance (49). Irradiation induces the stabilization of HIF- $1 \alpha$ protein in glioma cells, thereby promoting angiogenesis and malignant progression (50). HIF- $1 \alpha$ regulates multiple genes and signaling pathways including cancer

TABLE 1 | Comprehensive summary of clinical trials associated with immunosuppressive pathways regulated by radiation therapy (RT).

\begin{tabular}{|c|c|c|c|c|c|}
\hline $\begin{array}{l}\text { Pathway } \\
\text { targeted }\end{array}$ & Immunotherapy & $\mathrm{RT}$ regimen & Condition & Status and phase & Identifier \\
\hline \multirow[t]{5}{*}{$\begin{array}{l}\text { TGF } \beta \text {-mediated } \\
\text { inhibition }\end{array}$} & Galunisertib (LY2157299) - TGF $\beta$ antagonist & $\begin{array}{l}\text { Stereotactic body } \\
\text { radiotherapy }\end{array}$ & $\begin{array}{l}\text { Hepatocellular } \\
\text { carcinoma }\end{array}$ & $\begin{array}{l}\text { Not yet recruiting } \\
\text { (Phase 1) }\end{array}$ & NCT02906397 \\
\hline & Galunisertib (LY2157299) - TGF $\beta$ antagonist & 7.5 Gy $\times 3$ fractions & Breast cancer & Recruiting (Phase 2) & NCT02538471 \\
\hline & Fresolimumab (GC1008)-TGF $\beta$ antagonist & 7.5 Gy $\times 3$ fractions & Breast cancer & Ongoing (Phase 2) & NCT01401062 \\
\hline & Galunisertib (LY2157299) - TGF $\beta$ antagonist & 1.8-2.0 Gy $\times 30$ fractions & Malignant glioma & Ongoing (Phase 1-2) & NCT01220271 \\
\hline & Fresolimumab (GC1008) - TGF $\beta$ antagonist & $\begin{array}{l}\text { Stereotactic ablative } \\
\text { radiotherapy }\end{array}$ & $\begin{array}{l}\text { Non-small cell lung } \\
\text { carcinoma }\end{array}$ & Recruiting (Phase 1-2) & NCT02581787 \\
\hline \multirow{4}{*}{$\begin{array}{l}\text { Tumor- } \\
\text { associated } \\
\text { macrophages- } \\
\text { recruitment and } \\
\text { polarization }\end{array}$} & Pexidartinib (PLX3397) - CSF1R inhibitor & Yes (dose not determined) & Prostate cancer & Recruiting (Phase 1) & NCT02472275 \\
\hline & Pexidartinib (PLX3397)-CSF1R inhibitor & $\begin{array}{l}60 \text { Gy ( } 5 \text { days/week for } \\
6 \text { weeks) }\end{array}$ & Glioblastoma & Ongoing (Phase 1-2) & NCT01790503 \\
\hline & Pexidartinib (PLX3397) - CSF1R inhibitor & No RT & $\begin{array}{l}\text { Tenosynovial giant cell } \\
\text { tumor }\end{array}$ & Ongoing (Phase 3) & NCT02371369 \\
\hline & $\begin{array}{l}\text { Carlumab (CNTO 888)-anti-CCL2 monoclonal } \\
\text { antibody }\end{array}$ & No RT & Prostate cancer & Completed (Phase 2) & NCT00992186 \\
\hline \multirow{2}{*}{$\begin{array}{l}\text { Adenosine- } \\
\text { mediated } \\
\text { inhibition }\end{array}$} & MEDI9447-CD73 inhibitor & No RT & $\begin{array}{l}\text { Advanced solid } \\
\text { tumors }\end{array}$ & Recruiting (Phase 1) & NCT02503774 \\
\hline & Tozadenant (SYN115) - A2AR antagonist & No RT & Parkinson's disease & Completed (Phase 2-3) & NCT01283594 \\
\hline \multirow{4}{*}{$\begin{array}{l}\text { VEGF-A/HIF- } \\
1 \alpha \text {-mediated } \\
\text { inhibition }\end{array}$} & Bevacizumab - anti-VEGF monoclonal antibody & Yes (dose not determined) & $\begin{array}{l}\text { Glioblastoma } \\
\text { multiforme }\end{array}$ & Ongoing (Phase 0) & NCT01091792 \\
\hline & $\begin{array}{l}\text { Sorafenib - protein kinase inhibitor targeting } \\
\text { VEGF receptor }\end{array}$ & 1.8 Gy daily for 5 weeks & Pancreatic cancer & Completed (Phase 1) & NCT00375310 \\
\hline & $\begin{array}{l}\text { Bevacizumab-anti-VEGF monoclonal antibody, } \\
\text { Temozolomid }\end{array}$ & $\begin{array}{l}60 \text { Gy (5 days/week for } \\
6 \text { weeks) }\end{array}$ & Glioblastoma & Ongoing (Phase 3) & NCT00884741 \\
\hline & Bevacizumab-anti-VEGF monoclonal antibody, & No RT & Metastatic melanoma & Ongoing (Phase 1) & NCT00790010 \\
\hline
\end{tabular}

Ipilimumab-anti-CTLA-4 monoclonal antibody 
cell survival, tumor neovascularization, and metabolism, which directly and indirectly impact antitumor immunity. Hypoxia can interfere with $\mathrm{T}$ cell effector function by selectively upregulating programmed death-ligand 1 (PD-L1) expression on both tumor cells and myeloid-derived suppressor cells (MDSCs) in a HIF-1 $\alpha$-dependent manner. Blockade of PD-L1 under hypoxia prevents $\mathrm{T}$ cell apoptosis and abrogates MDSC-mediated T cell suppression by modulating MDSCs cytokine production $(51,52)$.

Accumulating evidence indicates that hypoxia can also contribute to immune tolerance by regulating immunosuppressive cell populations. Facciabene et al. have demonstrated that hypoxic tumors promote the recruitment of Tregs via CCL28, which, in turn, dampen effector $\mathrm{T}$ cell function and promote angiogenesis (53). TAMs have been shown to inhibit T-cell proliferation under hypoxia in a HIF- $1 \alpha$-dependent manner in the murine MMTVPyMT model of breast cancer. Furthermore, targeted deletion of HIF- $1 \alpha$ in myeloid cells resulted in reduced tumor growth (54). Although tumor hypoxia does not influence the differentiation and/or polarization of TAMs, it does fine-tune the phenotype of the M2-like macrophage population (55). HIF- $1 \alpha$ also regulates MDSCs differentiation and function in the $\operatorname{TME}(51,56)$. Sceneay et al. have also reported that factors secreted by hypoxic tumors (driven by HIF-1 $\alpha$ signaling) condition the establishment of the premetastatic niche by recruiting granulocytic MDSCs and suppressing NK cell cytotoxicity (57).

As mentioned above, one important role of HIF- $1 \alpha$ is the stimulation of angiogenesis (58-60). In the absence of oxygen, HIF- $1 \alpha$ binds to hypoxia-response elements, thereby activating the expression of multiple hypoxia-response genes, including VEGF-A, which is produced by a majority of tumor cells, is present in the serum of cancer patients and whose expression is increased by RT (Figure 1) $(61,62)$. In addition to its direct pro-angiogenic properties, VEGF-A is also a potent immunosuppressive mediator in the TME. VEGFR2, one of its two key receptors, is selectively expressed by Foxp $3^{\text {high }} \mathrm{CD} 4^{+}$ Tregs and VEGF-A has been shown to induce Treg proliferation in a VEGFR2-dependent manner in tumor-bearing mice and metastatic colorectal cancer patients $(63,64)$. VEGF-A arrests the differentiation of myeloid cells, resulting in the accumulation of MDSCs $(65,66)$. Horikawa et al. have shown recently that the VEGF-A/VEGFR2 pathway increases intratumoral MDSCs and promotes tumor progression in a mouse ovarian cancer model. They also showed that VEGF expression correlated with MDSCs infiltration in human samples from the peritoneum of ovarian cancer patients with disseminated disease (67). Besides these effects on immunoregulatory cells, a direct inhibition of conventional $\mathrm{T}$ cells by VEGF-A has been reported (68). VEGF-A also enhances the expression of inhibitory receptors by CD8 ${ }^{+} \mathrm{T}$ cells (Tim-3, CTLA-4, PD-1, Lag-3) in a VEGFR2NFAT-dependent manner. Treatment of CT26 tumor-bearing mice with VEGF-A antibody decreases the expression of these inhibitory receptors on $\mathrm{CD}^{+} \mathrm{T}$ cells isolated from the tumor and from hepatic metastases (69). Recently, Motz et al. have demonstrated that VEGF-A together with IL-10 and PGE2 in hypoxic regions can induce Fas ligand expression on tumor endothelial cells, leading to the apoptosis of effector $\mathrm{CD}^{+}$ T cells (70).
Altogether, these data suggest that VEGF-targeted therapies could reverse immunosuppression and increase antitumor immunity. Notably, inhibiting VEGF-A pathway by neutralizing antibodies has been shown to increase the antitumor effects of ionizing radiation $(71,72)$. Currently, the most prominent VEGF pathway-targeting drug is bevacizumab; a recombinant humanized monoclonal antibody that binds to human VEGF-A. A combinatorial therapy targeting tumor hypoxia by using HIF- $1 \alpha$ or VEGF-A inhibitors along with RT and immunotherapy (PDL1 or other immune checkpoint inhibitor) may be beneficial for enhancing antitumor immunity in cancer patients.

\section{DUAL ROLE OF ADENOSINERGIC SIGNALING IN TUMORS FOLLOWING RT}

Adenosine accumulation in the TME has been identified as a central immunosuppressive factor $(73,74)$. ATP is the universal carrier of chemical energy and is present in all metabolically active cells. When released into the extracellular space following ICD, ATP triggers recruitment of DCs, and other antigenpresenting cells through $\mathrm{P} 2 \mathrm{Y} 2$ receptor-dependent chemotaxis (75). In addition, ATP constitutes an important activation signal for DCs by activating the NLRP3 inflammasome through ligation with the P2RX7 receptor (76). DCs are stimulated to produce pro-inflammatory cytokines IL- $1 \beta$ and IL-18, and they start to differentiate, allowing them to process engulfed tumor antigens, and migrate to the draining lymph nodes to cross-present the antigens to naïve $\mathrm{T}$ cells $(6,77,78)$.

RT has been shown to trigger release of ATP from tumor cells in a dose-dependent manner suggesting that ATP is a key mediator of radiation-induced antitumor immunity (5). However, ATP is rapidly catabolized in the TME by the action of ectonucleotidases CD39 (ecto-nucleoside triphosphate diphosphohydrolase 1) that catalyzes the hydrolysis of ATP into adenosine diphosphate $(\mathrm{ADP})$ and $\mathrm{ADP}$ into adenosine monophosphate (AMP). AMP is then converted into adenosine by irreversible hydrolysis catalyzed by CD73 (ecto-5'-nucleotidase), the ratelimiting enzyme for adenosine generation (79). Adenosine is a pleiotropic anti-inflammatory mediator that directly inhibits the activity of antigen-presenting cells and effector lymphocytes, primarily through uptake $v i a$ adenosine receptor $2 \mathrm{~A}$ (A2AR), and also indirectly by promoting proliferation of Tregs and skewing the polarization of TAMs from an M1 to an M2 phenotype (Figure 1) (80-82). Moreover, the expression of A2AR is upregulated under hypoxic conditions (83).

CD73 is expressed in a multitude of cancers and its significance in tumor progression is supported by studies showing that CD73 expression levels correlated with worse prognosis in triple-negative breast cancer as well as in gastric, colorectal, and gallbladder cancer (84-87). Moreover, preclinical studies have revealed that CD73-deficient mice have a suppressed growth of implanted tumors and are protected from experimental metastases (88). Although the expression of CD39 has not yet been correlated with tumor behavior or stage in patients, CD39 is overexpressed in some human tumor cells and co-culture of $\mathrm{CD}_{3} 9^{+}$tumor cells with activated $\mathrm{CD}^{+}$and $\mathrm{CD}^{+} \mathrm{T}$ cells suppressed $\mathrm{T}$ cell proliferation, which was abrogated in the 
presence of CD39-blocking antibody or A2AR inhibitor (89). Interestingly, CD39 and CD73 are also expressed by effector $\mathrm{T}$ cells, and their expression is regulated by the concentration of ATP metabolites in the extracellular milieu (90). Expression of CD39 and CD73 in Tregs correlates with their suppressive capacity, highlighting the plasticity and importance of adenosinergic signaling in regulating immune activation (91-94). Moreover, MDSCs express CD39 and CD73 and are sensitive to adenosine signaling, which affects their function and migration $(95,96)$. The suppressive activity of granulocytic MDSCs is increased in presence of AMP in vitro (97).

Stagg and colleagues have shown that pharmacological blockade of adenosine generation or uptake, by inhibition of CD73 or A2AR, respectively, promotes antitumor immune responses and synergizes with anti-PD-1 and anti-CTLA-4 (98-100). To date, little is known of the interplay between radiation and adenosine-mediated immunosuppression. However, our data suggest that the dose-dependent release of ATP following tumor irradiation along with a high ectonucleotidase expression in the TME may lead to increased adenosine levels following RT and limit the efficacy of radiation-induced in situ tumor vaccination (101).

\section{TGF $\beta$ AS A CENTRAL REGULATOR OF RT-INDUCED TUMOR IMMUNOGENICITY}

TGF $\beta$ is a multipotent cytokine involved in the regulation of cellular differentiation, survival, and function of many, if not all, immune-cell types (102-106). For instance, approximately 25 years ago, Shull and colleagues reported a massive activation and expansion of $\mathrm{T}$ cells in TGF $\beta 1$-deficient mice, indicating that one of the major roles of TGF $\beta$ is the regulation of T cell differentiation and function (107). Since then, TGF $\beta$ has been demonstrated to inhibit the functional differentiation of $\mathrm{CD}^{+}$ $\mathrm{T}$ cells into CTLs and to actively contribute to the conversion of naïve CD4+ $\mathrm{T}$ cells into Tregs upon TCR cross-linking (108-110). TGF $\beta$ has also been reported to induce expression of CD73, and to a lesser extend CD39 in both $\mathrm{CD}^{+}$and $\mathrm{CD}^{+} \mathrm{T}$ cells (111). Chalmin and colleagues have corroborated these findings by showing that the expression of CD39 and CD73 is under TGF $\beta$ transcriptional control in in vitro generated Th17 cells via Stat 3 activation (112).

Immune regulation mediated by TGF $\beta$ extends far beyond the T cell compartment with TGF $\beta$ playing a key role in subverting adaptive immunity by inhibiting DCs activation and skewing the phenotype ofmacrophagesfrom M1 to M2 (113-116). Importantly, aside from their well-described role in host defenses, accumulating evidence indicate that neutrophils exhibit a high phenotypic and functional plasticity depending upon TGF $\beta$ available in the TME (117). Indeed, similar to macrophages, TGF $\beta$ has been shown to drive the phenotype change of a more tumor cytotoxic and pro-inflammatory phenotype (N1) into a tumor supportive phenotype (N2) (113). Radiation activates latent TGF $\beta$ through a conformational change of the latency-associated peptide-TGF $\beta$ complex releasing active TGF $\beta$ (Figure 1) $(118,119)$.

The role of TGF $\beta$ as a master regulator of RT-induced antitumor $\mathrm{T}$ cell responses was demonstrated in two mouse tumor models of breast cancer. Antibody-mediated neutralization of TGF $\beta$ was required to achieve RT-induced priming of CD8 $\mathrm{T}$ cells to multiple endogenous tumor antigens. Importantly, complete regression of the irradiated $4 \mathrm{~T} 1$ tumor and inhibition of spontaneous lung metastases was seen only in mice treated with RT in the presence of TGF $\beta$ neutralization and was mediated by $\mathrm{T}$ cells. Likewise, effective growth inhibition of non-irradiated synchronous subcutaneous TSA tumors required TGF $\beta$ neutralization together with RT to the contralateral TSA tumor, demonstrating an abscopal effect (120). These data highlight the importance of TGF $\beta$ mediated immunosuppression in the context of the irradiated tumor. While concurrent blockade of TGF $\beta$ with RT-achieved therapeutically effective antitumor immune responses able to extend mice survival, upregulation of PD-L1 in the irradiated tumor, detected on both carcinoma cells and infiltrating myeloid cells, was found to limit tumor rejection, leading to early tumor recurrence. Upregulation of PD-L1-following RT has been reported in several preclinical studies and is mediated via at least two distinct mechanisms. In relatively immunogenic tumors, RT alone was able to elicit antitumor $\mathrm{T}$ cells that infiltrated the tumor and produced interferon- $\gamma$ (IFN $\gamma)$, which in turn induced PD-L1 expression on tumor cells $(120,121)$. Similarly, PD-L1 upregulation was driven by effector $\mathrm{T}$ cell infiltration in a poorly immunogenic tumor after RT plus TGF $\beta$ blockade (120).

These data suggest that when RT alone or in combination with an immune modulator elicits $\mathrm{T}$ cell responses that are insufficient to reject the tumor, the upregulation of immune checkpoint molecules in response to immune attack limits tumor rejection (122). As discussed above, another mechanism of PD-L1 upregulation is mediated by RT-induced HIF- $1 \alpha(51,123)$. Thus, PD-1/PD-L1 axis may represent an important obstacle to RT-induced tumor rejection, a hypothesis currently being tested in several clinical studies (124).

\section{USING RADIOTHERAPY TO ENHANCE RESPONSES TO IMMUNOTHERAPY IN THE CLINIC}

Several therapeutics designed to counteract the accumulation or action of immunosuppressive mediators are undergoing testing in cancer patients, in some cases in combination with RT. Table 1 provides examples of clinical trials that investigate drugs targeting the suppressive pathways discussed above. We have not included trials testing RT with anti-PD-1 or anti-PD-L1 since the latter were discussed in several recent reviews (124-126).

Antiangiogenic therapy in the form of the anti-VEGF-A antibody bevacizumab has been tested in combination with the anti-CTLA-4 antibody ipilimumab in patients with metastatic melanoma demonstrating favorable clinical outcomes and was associated with improved tumor $\mathrm{T}$ cell infiltration (127, 128). Preclinical studies in colorectal cancer xenografts have demonstrated that inhibition of the VEGF receptor (VEGFR) with concomitant fractionated RT resulted in normalization of vasculature and improved tumor control compared to RT or VEGFR-inhibition alone (129). Hyperfractionated RT is 
currently being combined with bevacizumab in glioblastoma patients and with sorafenib (a protein kinase inhibitor targeting VEGFR) in patients with pancreatic cancer (NCT00884741, NCT00375310).

The central role of TGF $\beta$ in modulation of RT-induced tumor immunogenicity has prompted the combined use of RT and TGF $\beta$-inhibitors in clinical cancer trials. Following the development of the small molecule inhibitor of TGF $\beta$-receptor I galunisertib (LY2157299), its safety profile has been tested in clinical trials, where intermittent administration was shown to be safe in patients with advanced cancer $(130,131)$. TGF $\beta$ neutralization by the monoclonal antibody Fresolimumab (GC1008) was also shown to be without dose-limiting toxicity up to $15 \mathrm{mg} /$ $\mathrm{kg}$ in malignant melanoma and renal cell carcinoma (132). Fresolimumab is currently being tested in combination with hypofractionated RT in patients with metastatic breast cancer and lung cancer (NCT01401062, NCT02538471).

Inhibition of TAM recruitment or activation in solid tumors as a measure to reduce immune suppression and favor immunemediated antitumor activity is a promising therapeutic concept (36, 133). A phase I-II study of the CSF1R inhibitor PLX3397, which included 23 patients with advanced tenosynovial giant-cell tumors in the extension phase II part, showed promising results, with 12 patients having a partial response and 7 patients with stable disease. The median duration of responses was 8 months at the time of data cutoff (134). The CSF1R inhibitor PLX3397 is currently under investigation in patients with prostate cancer and glioblastoma in combination with RT (NCT02472275, NCT01790503). Moreover, safety and tolerability of an anti-CCL2 monoclonal antibody (carlumab, CNTO 888) as single therapy is under investigation in metastatic and castrate resistant prostate cancer (NCT00992186).

Although adenosine blockade has not been clinically tested in patients receiving RT, inhibitors of both adenosine conversion (anti-CD73 monoclonal antibodies) and adenosine uptake (A2AR-inhibitors) have been tested for safety and tolerability in patients with cancer and Parkinson's disease, respectively (NCT02503774, NCT01283594). Also in development for potential use in cancer patients are antibodies targeting CD39, which

\section{REFERENCES}

1. Gajewski TF, Schreiber H, Fu YX. Innate and adaptive immune cells in the tumor microenvironment. Nat Immunol (2013) 14(10):1014-22. doi:10.1038/ ni. 2703

2. Formenti SC, Demaria S. Radiation therapy to convert the tumor into an in situ vaccine. Int J Radiat Oncol Biol Phys (2012) 84(4):879-80. doi:10.1016/j. ijrobp.2012.06.020

3. Kepp O, Tesniere A, Schlemmer F, Michaud M, Senovilla L, Zitvogel $\mathrm{L}$, et al. Immunogenic cell death modalities and their impact on cancer treatment. Apoptosis (2009) 14(4):364-75. doi:10.1007/s10495-0080303-9

4. Frey B, Hehlgans S, Rödel F, Gaipl US. Modulation of inflammation by low and high doses of ionizing radiation: implications for benign and malign diseases. Cancer Lett (2015) 368(2):230-7. doi:10.1016/j.canlet. 2015.04.010

5. Golden EB, Frances D, Pellicciotta I, Demaria S, Helen Barcellos-Hoff M, Formenti SC. Radiation fosters dose-dependent and chemotherapy-induced immunogenic cell death. Oncoimmunology (2014) 3:e28518. doi:10.4161/ onci. 28518 could potentially provide the advantage of increasing extracellular ATP released during RT-induced ICD while simultaneously limiting the generation of adenosine precursors (135).

\section{CONCLUSION}

The use of localized RT as an adjuvant to immunotherapy with the goal of inducing in situ tumor vaccination is a promising concept for the treatment of cancer patients who lack a pre-existing immune response against their tumor. However, successful induction of antitumor immunity by RT is dependent upon the balance of the pre-existing immunosuppressive factors, and the immunosuppressive and immune-activating signals that are generated by RT. Improved understanding of the specific pathways that are enabled by RT, and of their mode of action, provides several novel actionable targets for inhibition to augment radiation-induced tumor immunogenicity. More studies are warranted to determine how to best leverage the new role of $\mathrm{RT}$ as an inducer of antitumor T cells.

\section{AUTHOR CONTRIBUTIONS}

EW designed and wrote the manuscript. CL, CV-B, KP, EG-M, and N-PR contributed to writing the manuscript and preparing the illustration and table. SD and SF edited the manuscript. All authors have read and approved the final version of the manuscript.

\section{FUNDING}

SD is supported by grants from NIH (R01 CA201246 and R01 CA198533) and from The Chemotherapy Foundation. SF and SD are supported by a grant from the Breast Cancer Research Foundation and SF is further supported by a grant from DOD BCRP (BC100481/W81XWH-11-1-0530). CV-B is supported by a post-doctoral fellowship from the DOD BCRP (W81XWH-13-1-0012). EW is supported by a post-doctoral fellowship from the DOD BCRP (BC160113). EG-M is supported by a grant from GEICAM.

6. Ma Y, Adjemian S, Yang H, Catani JP, Hannani D, Martins I, et al. ATP dependent recruitment, survival and differentiation of dendritic cell precursors in the tumor bed after anticancer chemotherapy. Oncoimmunology (2013) 2(6):e24568. doi:10.4161/onci.24568

7. Gameiro SR, Jammeh ML, Wattenberg MM, Tsang KY, Ferrone S, Hodge JW. Radiation-induced immunogenic modulation of tumor enhances antigen processing and calreticulin exposure, resulting in enhanced T-cell killing. Oncotarget (2014) 5(2):403-16. doi:10.18632/oncotarget.1719

8. Kulzer L, Rubner Y, Deloch L, Allgäuer A, Frey B, Fietkau R, et al. Norm- and hypo-fractionated radiotherapy is capable of activating human dendritic cells. J Immunotoxicol (2014) 11(4):328-36. doi:10.3109/ 1547691X.2014.880533

9. Apetoh L, Ghiringhelli F, Tesniere A, Criollo A, Ortiz C, Lidereau R, et al. The interaction between HMGB1 and TLR4 dictates the outcome of anticancer chemotherapy and radiotherapy. Immunol Rev (2007) 220:47-59. doi:10.1111/j.1600-065X.2007.00573.x

10. Matsumura S, Wang B, Kawashima N, Braunstein S, Badura M, Cameron TO, et al. Radiation-induced CXCL16 release by breast cancer cells attracts effector T cells. J Immunol (2008) 181(5):3099-107. doi:10.4049/ jimmunol.181.5.3099 
11. Lim JY, Gerber SA, Murphy SP, Lord EM. Type I interferons induced by radiation therapy mediate recruitment and effector function of $\mathrm{CD} 8(+)$ T cells. Cancer Immunol Immunother (2014) 63(3):259-71. doi:10.1007/ s00262-013-1506-7

12. Sridharan V, Margalit DN, Lynch SA, Severgnini M, Zhou J, Chau NG, et al. Definitive chemoradiation alters the immunologic landscape and immune checkpoints in head and neck cancer. Br J Cancer (2016) 115(2):252-60. doi:10.1038/bjc.2016.166

13. Lugade AA, Sorensen EW, Gerber SA, Moran JP, Frelinger JG, Lord EM. Radiation-induced IFN-gamma production within the tumor microenvironment influences antitumor immunity. J Immunol (2008) 180(5):3132-9. doi:10.4049/jimmunol.180.5.3132

14. Reits EA, Hodge JW, Herberts CA, Groothuis TA, Chakraborty M, Wansley EK, et al. Radiation modulates the peptide repertoire, enhances MHC class I expression, and induces successful antitumor immunotherapy. J Exp Med (2006) 203(5):1259-71. doi:10.1084/jem.20052494

15. Chakraborty M, Abrams SI, Camphausen K, Liu K, Scott T, Coleman CN, et al. Irradiation of tumor cells up-regulates Fas and enhances CTL lytic activity and CTL adoptive immunotherapy. J Immunol (2003) 170(12):6338-47. doi:10.4049/jimmunol.170.12.6338

16. Demaria S, Ng B, Devitt ML, Babb JS, Kawashima N, Liebes L, et al. Ionizing radiation inhibition of distant untreated tumors (abscopal effect) is immune mediated. Int J Radiat Oncol Biol Phys (2004) 58(3):862-70. doi:10.1016/j. ijrobp.2003.09.012

17. Dewan MZ, Galloway AE, Kawashima N, Dewyngaert JK, Babb JS, Formenti SC, et al. Fractionated but not single-dose radiotherapy induces an immune-mediated abscopal effect when combined with anti-CTLA-4 antibody. Clin Cancer Res (2009) 15(17):5379-88. doi:10.1158/1078-0432. CCR-09-0265

18. Golden EB, Demaria S, Schiff PB, Chachoua A, Formenti SC. An abscopal response to radiation and ipilimumab in a patient with metastatic non-small cell lung cancer. Cancer Immunol Res (2013) 1(6):365-72. doi:10.1158/23266066.CIR-13-0115

19. Brody JD, Ai WZ, Czerwinski DK, Torchia JA, Levy M, Advani RH, et al. In situ vaccination with a TLR9 agonist induces systemic lymphoma regression: a phase I/II study. J Clin Oncol (2010) 28(28):4324-32. doi:10.1200/ JCO.2010.28.9793

20. Golden EB, Chhabra A, Chachoua A, Adams S, Donach M, Fenton-Kerimian $\mathrm{M}$, et al. Local radiotherapy and granulocyte-macrophage colony-stimulating factor to generate abscopal responses in patients with metastatic solid tumours: a proof-of-principle trial. Lancet Oncol (2015) 16(7):795-803. doi:10.1016/S1470-2045(15)00054-6

21. Postow MA, Callahan MK, Barker CA, Yamada Y, Yuan J, Kitano S, et al. Immunologic correlates of the abscopal effect in a patient with melanoma. $N$ Engl J Med (2012) 366(10):925-31. doi:10.1056/NEJMoa1112824

22. Mittal D, Gubin MM, Schreiber RD, Smyth MJ. New insights into cancer immunoediting and its three component phases - elimination, equilibrium and escape. Curr Opin Immunol (2014) 27:16-25. doi:10.1016/j. coi.2014.01.004

23. Spranger S, Bao R, Gajewski TF. Melanoma-intrinsic beta-catenin signalling prevents anti-tumour immunity. Nature (2015) 523(7559):231-5. doi:10.1038/nature14404

24. Xu J, Escamilla J, Mok S, David J, Priceman S, West B, et al. CSF1R signaling blockade stanches tumor-infiltrating myeloid cells and improves the efficacy of radiotherapy in prostate cancer. Cancer Res (2013) 73(9):2782-94. doi:10.1158/0008-5472.CAN-12-3981

25. Frenguelli BG, Wigmore G, Llaudet E, Dale N. Temporal and mechanistic dissociation of ATP and adenosine release during ischaemia in the mammalian hippocampus. J Neurochem (2007) 101(5):1400-13. doi:10.1111/j.1471-4159.2007.04425.x

26. Bingle L, Brown NJ, Lewis CE. The role of tumour-associated macrophages in tumour progression: implications for new anticancer therapies. J Pathol (2002) 196(3):254-65. doi:10.1002/path.1027

27. O'Shea JJ, Murray PJ. Cytokine signaling modules in inflammatory responses. Immunity (2008) 28(4):477-87. doi:10.1016/j.immuni.2008.03.002

28. Qian BZ, Li J, Zhang H, Kitamura T, Zhang J, Campion LR, et al. CCL2 recruits inflammatory monocytes to facilitate breast-tumour metastasis. Nature (2011) 475(7355):222-5. doi:10.1038/nature10138
29. Qian B, Deng Y, Im JH, Muschel RJ, Zou Y, Li J, et al. A distinct macrophage population mediates metastatic breast cancer cell extravasation, establishment and growth. PLoS One (2009) 4(8):e6562. doi:10.1371/journal. pone. 0006562

30. Pollard JW. Macrophages define the invasive microenvironment in breast cancer. J Leukoc Biol (2008) 84(3):623-30. doi:10.1189/jlb.1107762

31. Lin EY, Li JF, Gnatovskiy L, Deng Y, Zhu L, Grzesik DA, et al. Macrophages regulate the angiogenic switch in a mouse model of breast cancer. Cancer Res (2006) 66(23):11238-46. doi:10.1158/0008-5472.CAN-06-1278

32. Vatner RE, Formenti SC. Myeloid-derived cells in tumors: effects of radiation. Semin Radiat Oncol (2015) 25(1):18-27. doi:10.1016/j.semradonc.2014. 07.008

33. Klug F, Prakash H, Huber PE, Seibel T, Bender N, Halama N, et al. Lowdose irradiation programs macrophage differentiation to an iNOS(+)/M1 phenotype that orchestrates effective $\mathrm{T}$ cell immunotherapy. Cancer Cell (2013) 24(5):589-602. doi:10.1016/j.ccr.2013.09.014

34. Hamilton JA. Colony-stimulating factors in inflammation and autoimmunity. Nat Rev Immunol (2008) 8(7):533-44. doi:10.1038/nri2356

35. Chitu V, Stanley ER. Colony-stimulating factor- 1 in immunity and inflammation. Curr Opin Immunol (2006) 18(1):39-48. doi:10.1016/j.coi. 2005.11.006

36. Priceman SJ, Sung JL, Shaposhnik Z, Burton JB, Torres-Collado AX, Moughon DL, et al. Targeting distinct tumor-infiltrating myeloid cells by inhibiting CSF-1 receptor: combating tumor evasion of antiangiogenic therapy. Blood (2010) 115(7):1461-71. doi:10.1182/blood-2009-08-237412

37. DeNardo DG, Brennan DJ, Rexhepaj E, Ruffell B, Shiao SL, Madden SF, et al. Leukocyte complexity predicts breast cancer survival and functionally regulates response to chemotherapy. Cancer Discov (2011) 1(1):54-67. doi:10.1158/2159-8274.CD-10-0028

38. Lin EY, Gouon-Evans V, Nguyen AV, Pollard JW. The macrophage growth factor CSF-1 in mammary gland development and tumor progression. JMammary Gland Biol Neoplasia (2002) 7(2):147-62. doi:10.102 3/A:1020399802795

39. Sharma M, Beck AH, Webster JA, Espinosa I, Montgomery K, Varma S, et al. Analysis of stromal signatures in the tumor microenvironment of ductal carcinoma in situ. Breast Cancer Res Treat (2010) 123(2):397-404. doi:10.1007/ s10549-009-0654-0

40. Beck AH, Espinosa I, Edris B, Li R, Montgomery K, Zhu S, et al. The macrophage colony-stimulating factor 1 response signature in breast carcinoma. Clin Cancer Res (2009) 15(3):778-87. doi:10.1158/1078-0432.CCR08-1283

41. Kalbasi A, Komar C, Tooker GM, Liu M, Lee JW, Gladney WL, et al. Tumorderived CCL2 mediates resistance to radiotherapy in pancreatic ductal adenocarcinoma. Clin Cancer Res (2017) 23(1):137-48. doi:10.1158/1078-0432. CCR-16-0870

42. Sanford DE, Belt BA, Panni RZ, Mayer A, Deshpande AD, Carpenter D, et al. Inflammatory monocyte mobilization decreases patient survival in pancreatic cancer: a role for targeting the CCL2/CCR2 axis. Clin Cancer Res (2013) 19(13):3404-15. doi:10.1158/1078-0432.CCR-13-0525

43. Li X, Yao W, Yuan Y, Chen P, Li B, Li J, et al. Targeting of tumour-infiltrating macrophages via CCL2/CCR2 signalling as a therapeutic strategy against hepatocellular carcinoma. Gut (2017) 66(1):157-67. doi:10.1136/ gutjnl-2015-310514

44. Pienta KJ, Machiels JP, Schrijvers D, Alekseev B, Shkolnik M, Crabb SJ, et al. Phase 2 study of carlumab (CNTO 888), a human monoclonal antibody against CC-chemokine ligand 2 (CCL2), in metastatic castration-resistant prostate cancer. Invest New Drugs (2013) 31(3):760-8. doi:10.1007/ s10637-012-9869-8

45. Gilbert J, Lekstrom-Himes J, Donaldson D, Lee Y, Hu M, Xu J, et al. Effect of CC chemokine receptor 2 CCR2 blockade on serum C-reactive protein in individuals at atherosclerotic risk and with a single nucleotide polymorphism of the monocyte chemoattractant protein-1 promoter region. Am J Cardiol (2011) 107(6):906-11. doi:10.1016/j.amjcard.2010.11.005

46. de Zeeuw D, Bekker P, Henkel E, Hasslacher C, Gouni-Berthold I, Mehling $\mathrm{H}$, et al. The effect of CCR2 inhibitor CCX140-B on residual albuminuria in patients with type 2 diabetes and nephropathy: a randomised trial. Lancet Diabetes Endocrinol (2015) 3(9):687-96. doi:10.1016/S2213-8587 (15)00261-2 
47. Ishikawa H, Sakurai H, Hasegawa M, Mitsuhashi N, Takahashi M, Masuda N, et al. Expression of hypoxic-inducible factor 1alpha predicts metastasis-free survival after radiation therapy alone in stage IIIB cervical squamous cell carcinoma. Int J Radiat Oncol Biol Phys (2004) 60(2):513-21. doi:10.1016/j. ijrobp.2004.03.025

48. Aebersold DM, Burri P, Beer KT, Laissue J, Djonov V, Greiner RH, et al. Expression of hypoxia-inducible factor-1alpha: a novel predictive and prognostic parameter in the radiotherapy of oropharyngeal cancer. Cancer Res (2001) 61(7):2911-6.

49. Moeller BJ, Cao Y, Li CY, Dewhirst MW. Radiation activates HIF-1 to regulate vascular radiosensitivity in tumors: role of reoxygenation, free radicals, and stress granules. Cancer Cell (2004) 5(5):429-41. doi:10.1016/ S1535-6108(04)00115-1

50. Kim YH, Yoo KC, Cui YH, Uddin N, Lim EJ, Kim MJ, et al. Radiation promotes malignant progression of glioma cells through HIF-1alpha stabilization. Cancer Lett (2014) 354(1):132-41. doi:10.1016/j.canlet. 2014.07.048

51. Noman MZ, Desantis G, Janji B, Hasmim M, Karray S, Dessen P, et al. PD-L1 is a novel direct target of HIF-1alpha, and its blockade under hypoxia enhanced MDSC-mediated T cell activation. J Exp Med (2014) 211(5):781-90. doi:10.1084/jem.20131916

52. Barsoum IB, Smallwood CA, Siemens DR, Graham CH. A mechanism of hypoxia-mediated escape from adaptive immunity in cancer cells. Cancer Res (2014) 74(3):665-74. doi:10.1158/0008-5472.CAN-13-0992

53. Facciabene A, Peng X, Hagemann IS, Balint K, Barchetti A, Wang LP, et al. Tumour hypoxia promotes tolerance and angiogenesis via CCL28 and T(reg) cells. Nature (2011) 475(7355):226-30. doi:10.1038/nature10169

54. Doedens AL, Stockmann C, Rubinstein MP, Liao D, Zhang N, DeNardo DG, et al. Macrophage expression of hypoxia-inducible factor-1 alpha suppresses T-cell function and promotes tumor progression. Cancer Res (2010) 70(19):7465-75. doi:10.1158/0008-5472.CAN-10-1439

55. Laoui D, Van Overmeire E, Di Conza G, Aldeni C, Keirsse J, Morias Y, et al. Tumor hypoxia does not drive differentiation of tumor-associated macrophages but rather fine-tunes the M2-like macrophage population. Cancer Res (2014) 74(1):24-30. doi:10.1158/0008-5472.CAN-13-1196

56. Corzo CA, Thomas C, Lily L, Matthew JC, Je-In Y, Pingyan C, et al. HIF1alpha regulates function and differentiation of myeloid-derived suppressor cells in the tumor microenvironment. J Exp Med (2010) 207(11):2439-53. doi:10.1084/jem.20100587

57. Sceneay J, Chow MT, Chen A, Halse HM, Wong CS, Andrews DM, et al. Primary tumor hypoxia recruits CD11b+/Ly6Cmed/Ly6G+ immune suppressor cells and compromises NK cell cytotoxicity in the premetastatic niche. Cancer Res (2012) 72(16):3906-11. doi:10.1158/0008-5472.CAN11-3873

58. Carmeliet P, Dor Y, Herbert JM, Fukumura D, Brusselmans K, Dewerchin M, et al. Role of HIF-1alpha in hypoxia-mediated apoptosis, cell proliferation and tumour angiogenesis. Nature (1998) 394(6692):485-90. doi:10.1038/ 28867

59. Du R, Lu KV, Petritsch C, Liu P, Ganss R, Passegué E, et al. HIF1alpha induces the recruitment of bone marrow-derived vascular modulatory cells to regulate tumor angiogenesis and invasion. Cancer Cell (2008) 13(3):206-20. doi:10.1016/j.ccr.2008.01.034

60. Ahn GO, Seita J, Hong BJ, Kim YE, Bok S, Lee CJ, et al. Transcriptional activation of hypoxia-inducible factor-1 (HIF-1) in myeloid cells promotes angiogenesis through VEGF and S100A8. Proc Natl Acad Sci U S A (2014) 111(7):2698-703. doi:10.1073/pnas.1320243111

61. Lund EL, Høg A, Olsen MW, Hansen LT, Engelholm SA, Kristjansen PE. Differential regulation of VEGF, HIFlalpha and angiopoietin- $1,-2$ and -4 by hypoxia and ionizing radiation in human glioblastoma. Int J Cancer (2004) 108(6):833-8. doi:10.1002/ijc.11662

62. Ferrara N, Davis-Smyth T. The biology of vascular endothelial growth factor. Endocr Rev (1997) 18(1):4-25. doi:10.1210/edrv.18.1.0287

63. Terme M, Pernot S, Marcheteau E, Sandoval F, Benhamouda N, Colussi O, et al. VEGFA-VEGFR pathway blockade inhibits tumor-induced regulatory T-cell proliferation in colorectal cancer. Cancer Res (2013) 73(2):539-49. doi:10.1158/0008-5472.CAN-12-2325

64. Suzuki H, Onishi H, Wada J, Yamasaki A, Tanaka H, Nakano K, et al. VEGFR2 is selectively expressed by FOXP3high CD4+ Treg. Eur J Immunol (2010) 40(1):197-203. doi:10.1002/eji.200939887
65. Huang Y, Chen X, Dikov MM, Novitskiy SV, Mosse CA, Yang L, et al. Distinct roles of VEGFR-1 and VEGFR-2 in the aberrant hematopoiesis associated with elevated levels of VEGF. Blood (2007) 110(2):624-31. doi:10.1182/ blood-2007-01-065714

66. Gabrilovich D, Ishida T, Oyama T, Ran S, Kravtsov V, Nadaf S, et al. Vascular endothelial growth factor inhibits the development of dendritic cells and dramatically affects the differentiation of multiple hematopoietic lineages in vivo. Blood (1998) 92(11):4150-66.

67. Horikawa N, Abiko K, Matsumura N, Hamanishi J, Baba T, Yamaguchi K, et al. Expression of vascular endothelial growth factor in ovarian cancer inhibits tumor immunity through the accumulation of myeloid-derived suppressor cells. Clin Cancer Res (2017) 23(2):587-99. doi:10.1158/10780432.CCR-16-0387

68. Ziogas AC, Gavalas NG, Tsiatas M, Tsitsilonis O, Politi E, Terpos E, et al. VEGF directly suppresses activation of $\mathrm{T}$ cells from ovarian cancer patients and healthy individuals via VEGF receptor type 2. Int J Cancer (2012) 130(4):857-64. doi:10.1002/ijc.26094

69. Voron T, Colussi O, Marcheteau E, Pernot S, Nizard M, Pointet AL, et al. VEGF-A modulates expression of inhibitory checkpoints on CD8+ T cells in tumors. J Exp Med (2015) 212(2):139-48. doi:10.1084/jem.20140559

70. Motz GT, Santoro SP, Wang LP, Garrabrant T, Lastra RR, Hagemann IS, et al. Tumor endothelium FasL establishes a selective immune barrier promoting tolerance in tumors. Nat Med (2014) 20(6):607-15. doi:10.1038/ nm.3541

71. Gorski DH, Beckett MA, Jaskowiak NT, Calvin DP, Mauceri HJ, Salloum $\mathrm{RM}$, et al. Blockage of the vascular endothelial growth factor stress response increases the antitumor effects of ionizing radiation. Cancer Res (1999) 59(14):3374-8.

72. Geng L, Donnelly E, McMahon G, Lin PC, Sierra-Rivera E, Oshinka H, et al. Inhibition of vascular endothelial growth factor receptor signaling leads to reversal of tumor resistance to radiotherapy. Cancer Res (2001) 61(6):2413-9.

73. Allard B, Beavis PA, Darcy PK, Stagg J. Immunosuppressive activities of adenosine in cancer. Curr Opin Pharmacol (2016) 29:7-16. doi:10.1016/j. coph.2016.04.001

74. Sitkovsky MV, Lukashev D, Apasov S, Kojima H, Koshiba M, Caldwell C, et al. Physiological control of immune response and inflammatory tissue damage by hypoxia-inducible factors and adenosine A2A receptors. Annu Rev Immunol (2004) 22:657-82. doi:10.1146/annurev.immunol.22.012703. 104731

75. Ma Y, Adjemian S, Mattarollo SR, Yamazaki T, Aymeric L, Yang H, et al. Anticancer chemotherapy-induced intratumoral recruitment and differentiation of antigen-presenting cells. Immunity (2013) 38(4):729-41. doi:10.1016/j.immuni.2013.03.003

76. Gombault A, Baron L, Couillin I. ATP release and purinergic signaling in NLRP3 inflammasome activation. Front Immunol (2013) 3:414. doi:10.3389/ fimmu.2012.00414

77. Kepp O, Galluzzi L, Martins I, Schlemmer F, Adjemian S, Michaud M, et al. Molecular determinants of immunogenic cell death elicited by anticancer chemotherapy. Cancer Metastasis Rev (2011) 30(1):61-9. doi:10.1007/ s10555-011-9273-4

78. Aymeric L, Apetoh L, Ghiringhelli F, Tesniere A, Martins I, Kroemer G, et al. Tumor cell death and ATP release prime dendritic cells and efficient anticancer immunity. Cancer Res (2010) 70(3):855-8. doi:10.1158/0008-5472. CAN-09-3566

79. Deaglio S, Robson SC. Ectonucleotidases as regulators of purinergic signaling in thrombosis, inflammation, and immunity. Adv Pharmacol (2011) 61:301-32. doi:10.1016/B978-0-12-385526-8.00010-2

80. Palmer TM, Trevethick MA. Suppression of inflammatory and immune responses by the $\mathrm{A}(2 \mathrm{~A})$ adenosine receptor: an introduction. Br J Pharmacol (2008) 153(Suppl 1):S27-34. doi:10.1038/sj.bjp.0707524

81. Ohta A, Kini R, Ohta A, Subramanian M, Madasu M, Sitkovsky M. The development and immunosuppressive functions of CD4(+) CD25(+) FoxP3(+) regulatory $\mathrm{T}$ cells are under influence of the adenosine-A2A adenosine receptor pathway. Front Immunol (2012) 3:190. doi:10.3389/fimmu. 2012.00190

82. Cekic C, Day YJ, Sag D, Linden J. Myeloid expression of adenosine A2A receptor suppresses $\mathrm{T}$ and $\mathrm{NK}$ cell responses in the solid tumor microenvironment. Cancer Res (2014) 74(24):7250-9. doi:10.1158/0008-5472.CAN13-3583 
83. Ahmad A, Ahmad S, Glover L, Miller SM, Shannon JM, Guo X, et al. Adenosine A2A receptor is a unique angiogenic target of HIF-2alpha in pulmonary endothelial cells. Proc Natl Acad Sci U S A (2009) 106(26):10684-9. doi:10.1073/pnas.0901326106

84. Loi S, Pommey S, Haibe-Kains B, Beavis PA, Darcy PK, Smyth MJ, et al. CD73 promotes anthracycline resistance and poor prognosis in triple negative breast cancer. Proc Natl Acad Sci U S A (2013) 110(27):11091-6. doi:10.1073/ pnas. 1222251110

85. Lu XX, Chen YT, Feng B, Mao XB, Yu B, Chu XY. Expression and clinical significance of CD73 and hypoxia-inducible factor-1alpha in gastric carcinoma. World J Gastroenterol (2013) 19(12):1912-8. doi:10.3748/wjg.v19.i12.1912

86. Wu XR, He XS, Chen YF, Yuan RX, Zeng Y, Lian L, et al. High expression of CD73 as a poor prognostic biomarker in human colorectal cancer. J Surg Oncol (2012) 106(2):130-7. doi:10.1002/jso.23056

87. Xiong L, Wen Y, Miao X, Yang Z. NT5E and FcGBP as key regulators of TGF-1-induced epithelial-mesenchymal transition (EMT) are associated with tumor progression and survival of patients with gallbladder cancer. Cell Tissue Res (2014) 355(2):365-74. doi:10.1007/s00441-013-1752-1

88. Stagg J, Divisekera U, Duret H, Sparwasser T, Teng MW, Darcy PK, et al. CD73-deficient mice have increased antitumor immunity and are resistant to experimental metastasis. Cancer Res (2011) 71(8):2892-900. doi:10.1158/0008-5472.CAN-10-4246

89. Bastid J, Regairaz A, Bonnefoy N, Déjou C, Giustiniani J, Laheurte C, et al. Inhibition of CD39 enzymatic function at the surface of tumor cells alleviates their immunosuppressive activity. Cancer Immunol Res (2015) 3(3):254-65. doi:10.1158/2326-6066.CIR-14-0018

90. Umansky V, Shevchenko I, Bazhin AV, Utikal J. Extracellular adenosine metabolism in immune cells in melanoma. Cancer Immunol Immunother (2014) 63(10):1073-80. doi:10.1007/s00262-014-1553-8

91. Mandapathil M, Hilldorfer B, Szczepanski MJ, Czystowska M, Szajnik M, Ren J, et al. Generation and accumulation of immunosuppressive adenosine by human CD4+CD25highFOXP3+ regulatory T cells. J Biol Chem (2010) 285(10):7176-86. doi:10.1074/jbc.M109.047423

92. Knapp K, Zebisch M, Pippel J, El-Tayeb A, Müller CE, Sträter N. Crystal structure of the human ecto-5'-nucleotidase (CD73): insights into the regulation of purinergic signaling. Structure (2012) 20(12):2161-73. doi:10.1016/j. str.2012.10.001

93. Strater N. Ecto-5'-nucleotidase: structure function relationships. Purinergic Signal (2006) 2(2):343-50. doi:10.1007/s11302-006-9000-8

94. Whiteside TL, Mandapathil M, Schuler P. The role of the adenosinergic pathway in immunosuppression mediated by human regulatory T cells (Treg). Curr Med Chem (2011) 18(34):5217-23. doi:10.2174/092986711798184334

95. Hyman MC, Petrovic-Djergovic D, Visovatti SH, Liao H, Yanamadala S, Bouis $\mathrm{D}$, et al. Self-regulation of inflammatory cell trafficking in mice by the leukocyte surface apyrase CD39. J Clin Invest (2009) 119(5):1136-49. doi:10.1172/JCI36433

96. Chen Y, Yao Y, Sumi Y, Li A, To UK, Elkhal A, et al. Purinergic signaling: a fundamental mechanism in neutrophil activation. Sci Signal (2010) 3(125):ra45. doi:10.1126/scisignal.2000549

97. Ryzhov S, Novitskiy SV, Goldstein AE, Biktasova A, Blackburn MR, Biaggioni I, et al. Adenosinergic regulation of the expansion and immunosuppressive activity of CD11b+Gr1+ cells. JImmunol (2011) 187(11):6120-9. doi:10.4049/jimmunol.1101225

98. Allard B, Pommey S, Smyth MJ, Stagg J. Targeting CD73 enhances the antitumor activity of anti-PD-1 and anti-CTLA-4 mAbs. Clin Cancer Res (2013) 19(20):5626-35. doi:10.1158/1078-0432.CCR-13-0545

99. Beavis PA, Milenkovski N, Henderson MA, John LB, Allard B, Loi S, et al. Adenosine receptor 2A blockade increases the efficacy of anti-PD-1 through enhanced antitumor T-cell responses. Cancer Immunol Res (2015) 3(5):506-17. doi:10.1158/2326-6066.CIR-14-0211

100. Iannone R, Miele L, Maiolino P, Pinto A, Morello S. Adenosine limits the therapeutic effectiveness of anti-CTLA4 $\mathrm{mAb}$ in a mouse melanoma model. Am J Cancer Res (2014) 4(2):172-81.

101. Wennerberg E, Kawashima N, Demaria S. Adenosine regulates radiation therapy-induced anti-tumor immunity. J Immunother Cancer (2015) 3(Suppl 2):378. doi:10.1186/2051-1426-3-S2-P378

102. Li MO, Wan YY, Sanjabi S, Robertson AK, Flavell RA. Transforming growth factor-beta regulation of immune responses. Annu Rev Immunol (2006) 24:99-146. doi:10.1146/annurev.immunol.24.021605.090737
103. Letterio JJ, Roberts AB. Regulation of immune responses by TGF-beta. Annu Rev Immunol (1998) 16:137-61. doi:10.1146/annurev.immunol. 16.1.137

104. Gros MJ, Naquet P, Guinamard RR. Cell intrinsic TGF-beta 1 regulation of B cells. JImmunol (2008) 180(12):8153-8. doi:10.4049/jimmunol.180. 12.8153

105. Li MO, Wan YY, Flavell RA. T cell-produced transforming growth factor-betal controls $\mathrm{T}$ cell tolerance and regulates Th1- and Th17-cell differentiation. Immunity (2007) 26(5):579-91. doi:10.1016/j.immuni.2007.03.014

106. Rubtsov YP, Rudensky AY. TGFbeta signalling in control of T-cell-mediated self-reactivity. Nat Rev Immunol (2007) 7(6):443-53. doi:10.1038/nri2095

107. Shull MM, Ormsby I, Kier AB, Pawlowski S, Diebold RJ, Yin M, et al. Targeted disruption of the mouse transforming growth factor-beta 1 gene results in multifocal inflammatory disease. Nature (1992) 359(6397):693-9. doi:10.1038/359693a0

108. Yamagiwa S, Gray JD, Hashimoto S, Horwitz DA. A role for TGF-beta in the generation and expansion of $\mathrm{CD} 4+\mathrm{CD} 25+$ regulatory $\mathrm{T}$ cells from human peripheral blood. J Immunol (2001) 166(12):7282-9. doi:10.4049/ jimmunol.166.12.7282

109. Chen W, Jin W, Hardegen N, Lei KJ, Li L, Marinos N, et al. Conversion of peripheral $\mathrm{CD} 4+\mathrm{CD} 25-$ naive $\mathrm{T}$ cells to $\mathrm{CD} 4+\mathrm{CD} 25+$ regulatory $\mathrm{T}$ cells by TGF-beta induction of transcription factor Foxp3. J Exp Med (2003) 198(12):1875-86. doi:10.1084/jem.20030152

110. Thomas DA, Massague J. TGF-beta directly targets cytotoxic T cell functions during tumor evasion of immune surveillance. Cancer Cell (2005) 8(5):369-80. doi:10.1016/j.ccr.2005.10.012

111. Regateiro FS, Howie D, Nolan KF, Agorogiannis EI, Greaves DR, Cobbold $\mathrm{SP}$, et al. Generation of anti-inflammatory adenosine by leukocytes is regulated by TGF-beta. Eur J Immunol (2011) 41(10):2955-65. doi:10.1002/ eji.201141512

112. Chalmin F, Mignot G, Bruchard M, Chevriaux A, Végran F, Hichami A, et al. Stat3 and Gfi-1 transcription factors control Th17 cell immunosuppressive activity via the regulation of ectonucleotidase expression. Immunity (2012) 36(3):362-73. doi:10.1016/j.immuni.2011.12.019

113. Fridlender ZG, Sun J, Kim S, Kapoor V, Cheng G, Ling L, et al. Polarization of tumor-associated neutrophil phenotype by TGF-beta: "N1" versus "N2" TAN. Cancer Cell (2009) 16(3):183-94. doi:10.1016/j.ccr.2009.06.017

114. Tanaka H, Shinto O, Yashiro M, Yamazoe S, Iwauchi T, Muguruma K, et al. Transforming growth factor beta signaling inhibitor, SB-431542, induces maturation of dendritic cells and enhances anti-tumor activity. Oncol Rep (2010) 24(6):1637-43. doi:10.3892/or_00001028

115. Gratchev A. TGF-beta signalling in tumour associated macrophages. Immunobiology (2017) 222(1):75-81. doi:10.1016/j.imbio.2015.11.016

116. Mantovani A, Sozzani S, Locati M, Allavena P, Sica A. Macrophage polarization: tumor-associated macrophages as a paradigm for polarized M2 mononuclear phagocytes. Trends Immunol (2002) 23(11):549-55. doi:10.1016/ S1471-4906(02)02302-5

117. Shaul ME, Levy L, Sun J, Mishalian I, Singhal S, Kapoor V, et al. Tumorassociated neutrophils display a distinct $\mathrm{N} 1$ profile following TGFbeta modulation: a transcriptomics analysis of pro-vs. antitumorTANs. Oncoimmunology (2016) 5(11):e1232221. doi:10.1080/2162402X.2016.1232221

118. Barcellos-Hoff MH, Derynck R, Tsang ML, Weatherbee JA. Transforming growth factor-beta activation in irradiated murine mammary gland. JClin Invest (1994) 93(2):892-9. doi:10.1172/JCI117045

119. Jobling MF, Mott JD, Finnegan MT, Jurukovski V, Erickson AC, Walian PJ, et al. Isoform-specific activation of latent transforming growth factor beta (LTGF-beta) by reactive oxygen species. Radiat Res (2006) 166(6):839-48. doi:10.1667/RR0695.1

120. Vanpouille-Box C, Diamond JM, Pilones KA, Zavadil J, Babb JS, Formenti $\mathrm{SC}$, et al. TGFbeta is a master regulator of radiation therapy-induced antitumor immunity. Cancer Res (2015) 75(11):2232-42. doi:10.1158/0008-5472. CAN-14-3511

121. Dovedi SJ, Adlard AL, Lipowska-Bhalla G, McKenna C, Jones S, Cheadle EJ, et al. Acquired resistance to fractionated radiotherapy can be overcome by concurrent PD-L1 blockade. Cancer Res (2014) 74(19):5458-68. doi:10.1158/0008-5472.CAN-14-1258

122. Taube JM, Anders RA, Young GD, Xu H, Sharma R, McMiller TL, et al. Colocalization of inflammatory response with B7-h1 expression in human melanocytic lesions supports an adaptive resistance mechanism 
of immune escape. Sci Transl Med (2012) 4(127):127ra37. doi:10.1126/ scitranslmed.3003689

123. Ruf M, Moch H, Schraml P. PD-L1 expression is regulated by hypoxia inducible factor in clear cell renal cell carcinoma. Int J Cancer (2016) 139(2):396-403. doi:10.1002/ijc.30077

124. Kang J, Demaria S, Formenti S. Current clinical trials testing the combination of immunotherapy with radiotherapy. JImmunother Cancer (2016) 4:51. doi:10.1186/s40425-016-0156-7

125. Pilones KA, Vanpouille-Box C, Demaria S. Combination of radiotherapy and immune checkpoint inhibitors. Semin Radiat Oncol (2015) 25(1):28-33. doi:10.1016/j.semradonc.2014.07.004

126. Vacchelli E, Bloy N, Aranda F, Buqué A, Cremer I, Demaria S, et al. Trial watch: immunotherapy plus radiation therapy for oncological indications. Oncoimmunology (2016) 5(9):e1214790. doi:10.1080/21624 02X.2016.1214790

127. Hodi FS, Lawrence D, Lezcano C, Wu X, Zhou J, Sasada T, et al. Bevacizumab plus ipilimumab in patients with metastatic melanoma. Cancer Immunol Res (2014) 2(7):632-42. doi:10.1158/2326-6066.CIR-14-0053

128. Wu X, Giobbie-Hurder A, Liao X, Lawrence D, McDermott D, Zhou J, et al. VEGF neutralization plus CTLA-4 blockade alters soluble and cellular factors associated with enhancing lymphocyte infiltration and humoral recognition in melanoma. Cancer Immunol Res (2016) 4(10):858-68. doi:10.1158/23266066.CIR-16-0084

129. Melsens E, Verberckmoes B, Rosseel N, Vanhove C, Descamps B, Pattyn P, et al. The VEGFR inhibitor cediranib improves the efficacy of fractionated radiotherapy in a colorectal cancer xenograft model. Eur Surg Res (2016) 58(3-4):95-108. doi:10.1159/000452741

130. Rodon J, Carducci MA, Sepulveda-Sánchez JM, Azaro A, Calvo E, Seoane $J$, et al. First-in-human dose study of the novel transforming growth factor-beta receptor I kinase inhibitor LY2157299 monohydrate in patients with advanced cancer and glioma. Clin Cancer Res (2015) 21(3):553-60. doi:10.1158/1078-0432.CCR-14-1380
131. Kovacs RJ, Maldonado G, Azaro A, Fernández MS, Romero FL, SepulvedaSánchez JM, et al. Cardiac safety of TGF-beta receptor I kinase inhibitor LY2157299 monohydrate in cancer patients in a first-in-human dose study. Cardiovasc Toxicol (2015) 15(4):309-23. doi:10.1007/s12012-014-9297-4

132. Morris JC, Tan AR, Olencki TE, Shapiro GI, Dezube BJ, Reiss M, et al. Phase I study of GC1008 (fresolimumab): a human anti-transforming growth factor-beta (TGFbeta) monoclonal antibody in patients with advanced malignant melanoma or renal cell carcinoma. PLoS One (2014) 9(3):e90353. doi:10.1371/journal.pone. 0090353

133. Allavena P, Sica A, Solinas G, Porta C, Mantovani A. The inflammatory micro-environment in tumor progression: the role of tumor-associated macrophages. Crit Rev Oncol Hematol (2008) 66(1):1-9. doi:10.1016/j. critrevonc.2007.07.004

134. Tap WD, Wainberg ZA, Anthony SP, Ibrahim PN, Zhang C, Healey JH, et al. Structure-guided blockade of CSF1R kinase in tenosynovial giant-cell tumor. N Engl J Med (2015) 373(5):428-37. doi:10.1056/NEJMoa1411366

135. Bonnefoy N, Bastid J, Alberici G, Bensussan A, Eliaou JF. CD39: a complementary target to immune checkpoints to counteract tumor-mediated immunosuppression. Oncoimmunology (2015) 4(5):e1003015. doi:10.1080/ 2162402X.2014.1003015

Conflict of Interest Statement: The authors declare that the research was conducted in the absence of any commercial or financial relationships that could be construed as a potential conflict of interest.

Copyright $\odot 2017$ Wennerberg, Lhuillier, Vanpouille-Box, Pilones, García-Martínez, Rudqvist, Formenti and Demaria. This is an open-access article distributed under the terms of the Creative Commons Attribution License (CC BY). The use, distribution or reproduction in other forums is permitted, provided the original author(s) or licensor are credited and that the original publication in this journal is cited, in accordance with accepted academic practice. No use, distribution or reproduction is permitted which does not comply with these terms. 